\title{
ПЕРСПЕКТИВИ РОЗВИТКУ СТОМАТОЛОГІЧНОГО ФАКУЛЬТЕТУ
}

\author{
Я. П. Нагірний \\ ДВНЗ “Тернопільський держсвний медичний університет імені I. Я. Горбачевського \\ МОЗ Украӥни” \\ DEVELOPMENT PROSPECTS OF STOMATOLOGICAL FACULTY \\ Ya. P. Nahirnyi \\ SHEI "Ternopil State Medical University by I. Ya. Horbachevsky of MPH of Ukraine”
}

\begin{abstract}
У статті окреслено основні напрямки розвитку стоматологічного факультету на найближчу перспективу. Вказано на необхідність модернізації матеріальної бази, удосконалення навчально-методичного процесу, розвиток наукових програм, покращання кадрового забезпечення.
\end{abstract}

The article adduces the main directions of stomatological faculty development for the nearest prospect. It is pointed out the necessity of modernization of material base, improvement of educational and methodical process, development of scientific programs, amelioration of stuff supply.

Вступ. Стратегічними напрямками розвитку стоматологічного факультету на найближчу перспективу є підвищення якості освіти і наукових розробок, подальша поетапна реалізація положень, визначених основними напрямами державної політики та міжнародними угодами України, активна участь у формуванні єдиного європейського освітнього та наукового простору, підвищення престижу ТДМУ ім. І. Я. Горбачевського. Пріоритетну увагу слід приділити сфері навчально-методичної роботи, формуванню інноваційного освітнього середовища, подальшому впровадженню європейської кредитно-трансферної системи і іiі складової - кредитно-модульної системи навчання, удосконаленню навчально-методичного забезпечення, методичного та інформаційного супроводу навчально-виховного процесу, форм і методів навчання, підвищенню кваліфікації науково-педагогічних працівників, запровадженню нових педагогічних та інформаційних технологій, рейтинговому оцінюванню знань студентів з метою підвищення якості освітніх послуг.

Основна частина. Підвищення якості підготовки фахівців у галузі “Стоматологія” повинно базуватись на прогнозуванні перспектив подальшого розвитку галузі, забезпечення виконання покладених на неї завдань на внутрішньому ринку праці і забезпеченню їі конкурентоспроможності на європейському, а в подальшому - і на світовому. Для забезпечення цього необхідно:

- створити на факультеті групу інноваційного розвитку з метою прогнозування майбутніх перспектив галузі;
- сприяти популяризації стоматологічного факультету через засоби масової інформації- телебачення, друковані видання, журнал “Клінічна стоматологія"; - вдосконалити форми і методи профорієнтаційної та агітаційної роботи серед майбутніх абітурієнтів, які будуть вступати на стоматологічний факультет;

- розширити обсяг прийому іноземних громадян на навчання за спеціальністю "Стоматологія”;

- забезпечити подальшу реалізацію основних засад кадрової політики шляхом подальшого залучення талановитої молоді до викладацької роботи та створення умов для іiї професійного зростання;

- розширити можливості для стажування фахівців університету у провідних європейських та світових науково-освітніх центрах;

-інтенсифікувати підготовку науково-педагогічних кадрів;

- забезпечити координацію зусиль кафедр університету з підготовки сучасної навчально-методичної літератури та нових навчальних програм для впровадження кредитно-модульної системи організації навчального процесу;

- активізувати укладання угод про взаємний обмін викладачами із зарубіжними освітніми закладами для підвищення педагогічної та професійної майстерності.

Важливою складовою навчально-виховного процесу $\epsilon$ методична робота, спрямована на вирішення завдань 3 підвищення якості підготовки фахівців на основі комплексного підходу до вдосконалення змісту, організації й методів навчання відповідно до вимог Болонської декларації за такими напрямками: 
- підготовка навчальних підручників та посібників, забезпечення необхідного рівня координації зусиль кафедр університету з підготовки сучасної навчально-методичної літератури. Активно впроваджувати в навчальний процес телекомунікаційні технології;

- забезпечення застосування в навчальному процесі сучасних наукових досягнень, які базуються на засадах доказової медицини;

- удосконалення методичного забезпечення навчального процесу шляхом удосконалення робочих програм по дисциплінах, активізація діяльності авторських колективів клінічних кафедр 3 підготовки і видання навчальної та навчально-методичної літератури;

- забезпечення функціонування безперервної системи дистанційного контролю знань 3 кожної дисципліни, моніторинг його якості;

- забезпечення якості підготовки тестових завдань 3 навчальних дисциплін для єдиного тестового іспиту та для щоденного дистанційного контролю за системою "Moodle", систематичного оновлення банку тестових завдань з врахуванням їх валідності;

- продовження роботи щодо розширення мережі клінічних баз та створення сучасних програм і методичного супроводу проведення виробничої практики студентів;

- розширення мережі навчально-практичних центрів 3 відповідним комп'ютерним забезпеченням для надання консультативної допомоги, розширення можливостей для освоєння студентами основних навичок, необхідних для подальшої професійної діяльності;

- активізація роботи по організації проведення практики за кордоном з метою збільшення кількості студентів, яким буде надана можливість проходження такої практики;

- удосконалення організації самостійної роботи студентів шляхом забезпечення всіма навчально-методичними засобами, необхідними для вивчення окремої теми. Вважати основними завданнями самостійної роботи студентів: поглиблення і розширення знань, формування інтересу до пізнавальної діяльності, оволодіння прийомами процесу пізнання, розвиток пізнавальних здібностей;

- впровадження інноваційних технологій в навчальний процес, запровадження веб-семінарів та веблекцій.

Бурхливий розвиток стоматології в останні роки нерозривно пов'язаний із зростанням рівня технічного забезпечення галузі. Засвоєння вже існуючих знань 3 відповідних дисциплін без проведення наукових досліджень не може забезпечити поступального розвитку стоматологічної науки. Тому прищеплення студентам навичок наукової роботи є необхідною умовою підготовки фахівця сучасного рівня. Для цього необхідно:

- активно залучати викладачів і студентську молодь до використання експериментальних досліджень за різними напрямками стоматології, а також представлення отриманих результатів на наукових форумах, конгресах, конкурсах всеукраїнського та міжнародного рівня;

- для створення необхідних умов для виконання дисертаційних робіт створити наукову лабораторію стоматологічного факультету;

- 3 метою надання допомоги у виконанні дисертаційних робіт використовувати сучасні інтерактивні технології з залученням досвідчених спеціалістів галузі;

- розширювати співпрацю з провідними вітчизняними та зарубіжними науково-дослідними установами 3 метою забезпечення необхідного рівня підготовки фахівців у галузі “Стоматологія”;

- систематично контролювати хід виконання дисертаційних робіт. Створювати для цього необхідні умови, матеріально заохочувати виконавців і наукових керівників.

Важливою проблемою, від вирішення якої залежить подальший розвиток факультету, є його комплектування кваліфікованими кадрами. Для цього необхідно по можливості контракт заключати з особами, які мають ступінь кандидата медичних наук із спеціальності 14.01.22 - стоматологія, а також проводити відбір перспективних студентів для викладацької роботи, підтримувати їх у виконанні дисертаційних робіт.

У сфері виховання зосередити зусилля на всебічному розвитку особистості студентів, формуванні у них активної громадянської позиції, почуття патріотизму, високих моральних якостей та духовних запитів, усвідомленні відповідальності за себе і суспільство в цілому, утвердженні здорового способу життя і заохоченні ініціативи. Виховувати у студентів почуття гордості за свою країну і університет. Організувати святкові заходи до Дня медичного працівника і Дня стоматолога. Запровадити розвиток співдружності стоматологічного факультету з іншими вітчизняними і зарубіжними навчальними закладами.

Висновок. Подальший розвиток стоматологічного факультету передбачає модернізацію матеріальної бази, удосконалення навчально-методичного процесу, розвиток наукових програм і кадрове забезпечення. Це дозволить створити найкращі умови для теоретичної і практичної підготовки лікарів-стоматологів в університеті. 